LA-UR - $81-3400$

\title{
MASTER
}

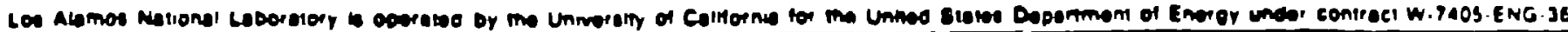

TITLE. DYNAMIC PARAMETER ARRAY SYSTEM (DPA

Autmon(S) G. T. Anderson

M. A. Oothoudt

J. F. Amann

T. Kozlowsk1

Submitted to Digltal Equipjent Computer Users Soclety.

December 7-11, 1981, Los Angeles, CA 
Gail T. Anderson

Michael A. Oothoudt

James F. Amann

Thomas Kozlowski

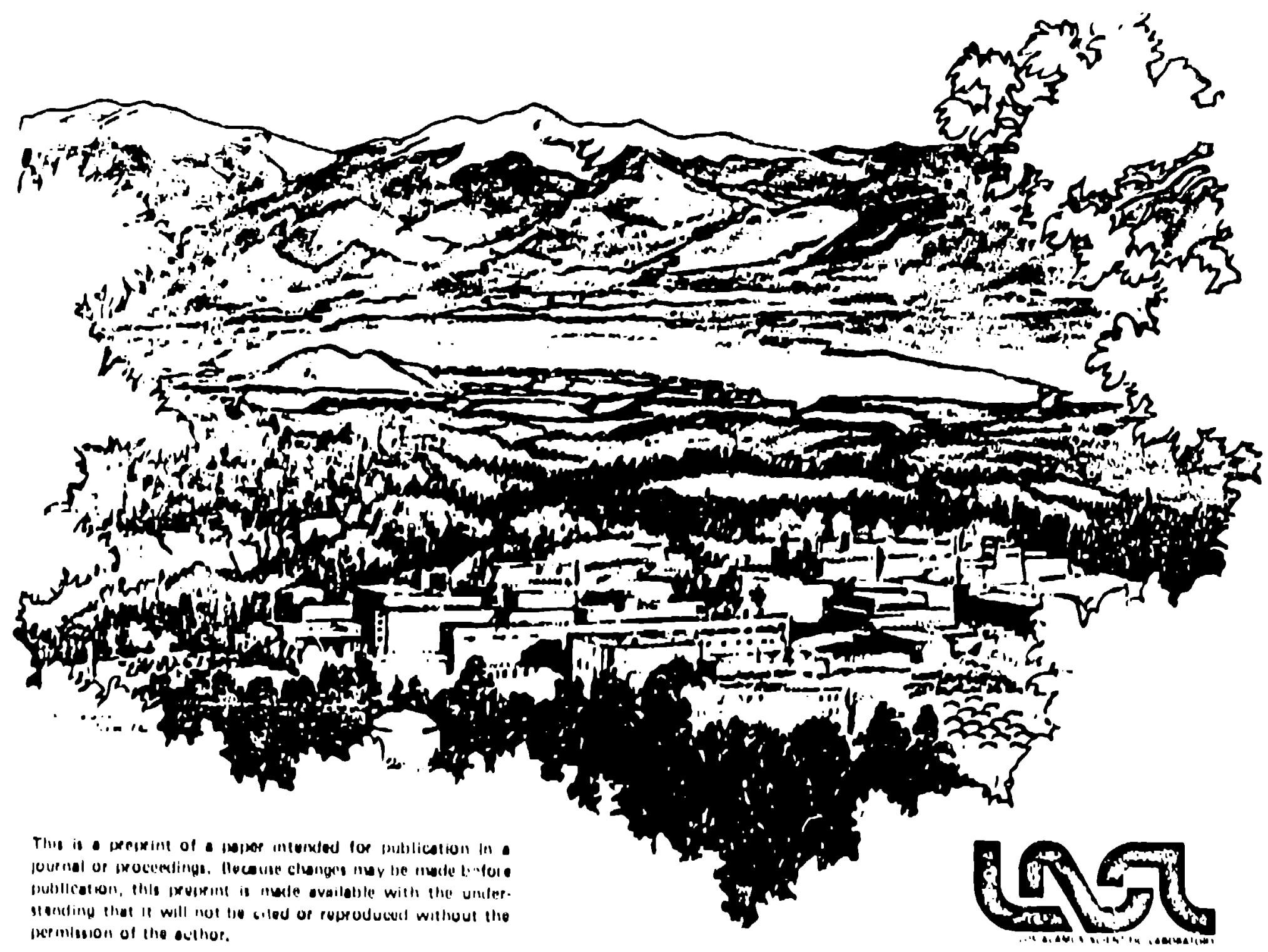




\section{DYNAMIC PARAMETER ARRAY SYSTEM}

(DPA)

Call T. Andergon

Michael A. Oothoude, Jamei F. Amann, end Thoras Kozlouskl

Los Alamos National Laboratory

Los Alamos, Nei Mexico

\section{ABSTRACT}

Mis paper describes coftuare which provides a aeans to change dynawleally (in :eal time) the values of paraneters in a ereculing task. The paramefers recide in an RSX-lil memory anageaent region or VMS ghared global section. Vallec way be accesced and altered ho any lask atcising the reglon. including an inceractive cack. The interacilve ensk aay be run from the keyboard to allou user inceraction with parameters etored in the repion. Keyboard comands allow the user to wake a diak lile copy of values in the region. modify values in the rcsion, and define meantngful wnonyos to usc in referring tu parapeters in the region.

\section{OLERLIFH OF THE SOTTEARF}

The purpose of DPA In to allow the user to change values of paracecs in a becifled user task uhile 1t 1t running. The cofevare conalete of a keybourd interface teak naged PRy and two eubroutines to be colled by user task to bet up azorage of the Daractera. The interactive caok PRM allowe the user read/urlte accese : 0 the paraseters frus thr refrinal or frow a cowand file. One oubrouline PRMCRE aay be called hy the uper's labk to create the cearv anagement region the parabeterd reelde In: the oller ouhrouilnc PRepup av be called by olher tasic to atech and ap the region.

The uter's cask ay define any number of INTrGfRe?, IFTECrReh, REALe4, and REALeR varlablen (erraye i, II, R, and RP reapectively) to be held in a seary gonagement reglun and he acceastble to other caske. Thene four orrays opr thosghe of a oubcectsons of a paracter arrav. These variablea are avallable for ue by the ueer' teoke vis a FCRTMAs COMON block.

Thle cof evare in uriteer in FLFCS.

This paper will dicouse ung the RSx-IIH version: the vas :erulon wild have identical functionality and ueer interfoce afthough ocouthat dfferent iaplesentetion where necescery.

Section II daseribe the hiocory leading up to the uriting of this coftuare and dilidetrates the needs

\footnotetext{
ft.le vork to eupported by the U. 5. Deperteent of Energv.

- Developed by Terry Beyer. Departaent of Computer Selence, Univernity of Oreson, Plics in a Fonthan pruprocessur alloulng uee if ofructured langure conatrueta in FORTMN.
}

to je met. Section 111 deucribes the wethod of toplewentation of DPA and the relationohit of DPA to oiher oystem roulines. Section IV detulle the functionaliev orovided from the nolnt of wieu of til user.

\section{HISTORY}

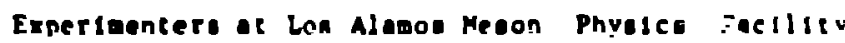
(LAMPF) frequently need to be able to thange perametere in eheir dota acoulestion propisa without going throuph the edit-cowplipetarinuld cyele. Pranoles of auch parancters are pains and pedestelc for deteclors, kinenatice parancter (anglea, energles, tarpet nases. elc.), calihration cuefficiente and teat libles. Note that mel peraecere eay be changed -everal linck an huur wich Deane changing "harduired" valued in cooe 18 ienractical.

A facsliev for changlng the parpsetera In one takk from enother taok was revelored by oeveral experisental groups. The $\bullet$ : ileat fun uncd was disk flle contalaing the necerary conscanta. The uner cank yuld be nnelfied of neu data to read h front panel cence oultelice and would reaci in the

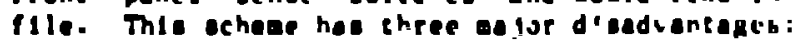

1. The disk 810 ia rugprativelv dow.

2. The diak :/O requiren a Jarar abunl $c$ code in the une:'s task.

3. The anoune of effore required to elvaly' it angle paraneter Is large, eince llit file Durt be edied aid even finding lie curri:" numer in the plite can hr tedioun. 
A schese used by James $F$. Amann under RSX-11D for two expertmental groups wag to use a Shared Clobal Area ( $S C A$ ) liniked to both a dita analysis task and an Input task. The Input task could be used to i $t$ variables in the SGA by comand, e.g." "RJ7-45.5." Such tasks nomally kept the parameters acored in a disk flle so that they could be restored after a reboot. Also, command flle input and a line printer listing of values were alloved. Such a wethod provides fast updaling of paradeters and even ailows slople wuleltask updating but does have iu dicadvaniages:

1. Thr SCA required $4 K$ vords of viriual address space in the uscr's takk even if only a feu hurdred paranctero exirted. The unused space was not easlly avallable to the user.

2. The profials did litile to help the uscr keep track of whlch varlables were whlch. For exasple, typlcal input 16 R37-45.5 10 set an angle, whereas THFTA-45.3 is really what the woer is thinklng ahout.

The Dymazic Parapeter Array orituare described hereln atcempis lo solve ehe virtual address brace problem and simpllfles the user incerfacc under RSX-1IH and vMS.

\section{IMPLEMENTATION}

Thls gectlon contalns:

- A discusiston of the rilacionghir betuecn the DPA sucted and other roultneg whlch moy thare the bevory manabegent reglon.

- A Mrlef desiripion of the iepledencacion meshod of each plece of the DPA coltuare.

\section{DPA's Envl:onecht}

The DPA eutevsted wlll he dietributed en lects an

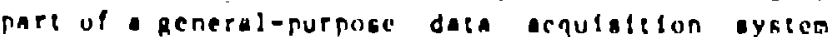
lised al LAYPF. But DPA can br used outelde the datn ecquidition environsent ulthoue any chanpen to DPA a all. Tor exapple lil Monce Carlo calculatione.

The conncction between DPA and offict ounpiled roulinc lakes place by ween of an RSX-IIM veropy mannecteill reglon uhich concaine the areay of parapeters to be charnd and aey almo concein other types of dace. The firet 32-vord bloct of the repton conceine en erray of offecta ineo the region (the Header erray HDR), which la followed by the atorake arean of the region. Thl elloug the reaton to be divided ineo 32 araan whleh any be uned for neperate purpunen, each of arhlerary leneth, cech of which oult begin an a j2-word boundary (for ease in wepplng).

\section{Detalle of Iepleoentalton}

This emction cuntalne enectfica of the CPA irplovensetion. The polnth dincunced are the atructure of the menory anagewent ruglon, creation of and sapping the reston, eccese tu the resion by the user at the rerolnal, and the disk flles asociated Uith DPA.

Seructure of the Region - Access to the da:a in the region 18 avallahle to any task which knous the "name" of zhe reglion. then the reglon is created, Its nawe is defined as the default lic inder which the creating task runs uith the first octal digtt translated to a letter; e.g., if the task whlch creates the region rune under UIC $[025,03])$, the name of the reglon 16 A2503\}. Thus any tisk running under the same UiC can access the reglon. The only Inforation bbout the beructure of th: regton needed hy a secordary lask whlch wust access data in the refion 16 that the firat 32-word block contalnk offseis to the ctorage oreas utthin the riglon. Therefore the task can map ro the first 32-ucro block, obtaln the necessary of scet, and tran remin to the requited information.

Flgure 1 is a sople vieu of the struciure of the reglon. Fach word in the Header array (the first) vords of the reaton! contains the offact to ihe associated storage area; e.R., the firot vord in the Header array polnts to the beglnning of the DPA parameter array whlch is alyys in the flet gtorage arca. Horda: and 3 of the Header array roint in the beginning addregaes of dapa for other data acquisition routines. Words 4 tlirough th are reacrued for future expansion. Words it ehroush 31 are ovaliable for aneclal purposes the uscr ony have. Hotd 32 of the Header array contalns the stze of the whole reglon. If any encry in the llender array contains $n$, the assoclated atorare section is nol used; e.p. Horda 4 through is will all contaln 0 for the precent releace of the DPA coftuert.

The advantege of thlo ofruceure la that it provides

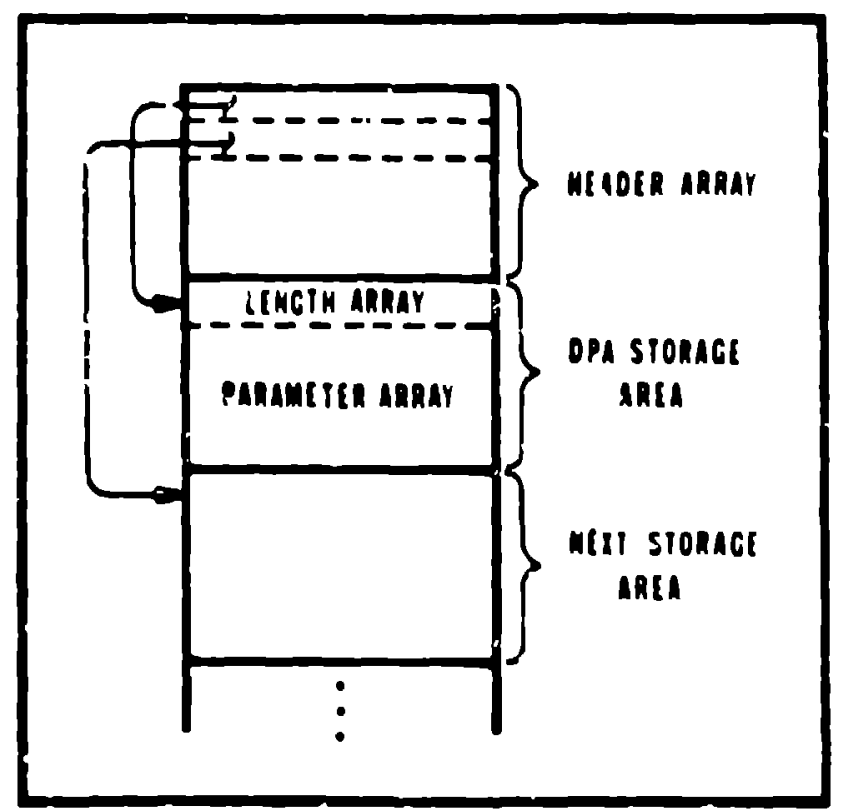

FICURR: I

siructure of elie liegury Maliager ent Hagion 
the ability to aake full wee of the mewory managewent region. Sirice virtual address apace used to the nap the region is allocated in $4 \mathrm{~K}$ word Increments, the abllity to place data other than the DPA paradeter array in the region allows the joer to use virtual addreas space that might otherulse be uasted. For example, if the region vere tc contaln only the parameter array anc the paraneter orray required only 1000 words, apprnximately 3000 words would be unused of the oinlwem. $4 K$ words allosated to map the reglon. Thio etructure allous use of the region to be based entirely upon the needs of the user without IIfIting hIt.

Creation of the Region - Date In the met ory managevent region 16 accessed by means of a FORTRAN COHQSOS block named RFCION In the tark which rrcaies the reglon: for example

INTECER=2 HDR ( J2), LFP:(4)

COPINS: /REGIO'./HUR, LEA, $1, R, 11, R R$, DLD, RF.ST

(The voriabler in Rfcios arc explained in the diacusiton of subruutine PR4CRE.) The parameler array is thought of as a single array made up of fuvi sectlons or sub-arreys (orrays I, $R, I I$, and RR): IIrGt is the INTEGER 2 secilon, uhlch contalne

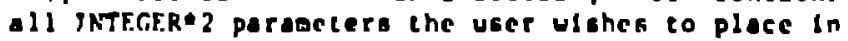
the reglon; next are all :he ReAL"4 paraeters; the itird cection contains all the INTFGFR 4 perancters; and the last sectlor, contalns the FEALeB parancters. The lengthe of the cuhscetiona of the erray way change os the cank Is developed, so four vords (an array nated LFN) are recerved to hold thr number of elitrles in each eection of the erray; l.e., LFN(I) contalns the nusher of ISTLCFR"? parancters placed in the region; LFN(2) the number of REAL*4 parameters, etc. Al lackhulld time Cotmos ReGIOA Is declared a virtual acction ulth the caskbullder VSECT option. The elarting addrese of the viriual eection Is the hase adoreng of an APK chosen to allos ruos iur the whule realen to he sapped by one

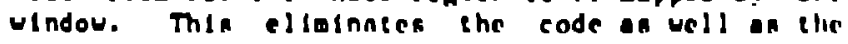
ime neceseary to perform resappina ns differcint woragc oreas in enp realon orc referciced.

Suhroutine PRMCRE If called hy the task uhlch eunt create the semory anageacnt replon. it creates and maps the region and placen mome necifle cuntrol dace In the refion; for inatence, this routine finds the lengtha of the mubections of the paraweter array and places these values In array LES.

Muping Ine Region. When the region to creaced hy phickt, The viole rexlon in mapped. This ollows :he ralding lagk lo accens lhr parameler array a voll ar any oelier inforation the ueer viahes to pue in the raxtall.

Subroue ine pruoup can ho called by any olher cank needing lo ou the peraneser array vithin the already ealating replull. in thle case only the paraneter array lo eapped.

The functiona perfolmed hy papal are at follow: The rouline forma the nase of the replon to be anpred froe the dofaule Vic of lie laok calling

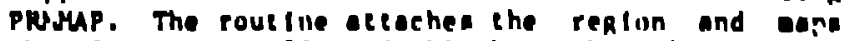
the firat tyo 32-uord hlocka. Ilbh(I) plves ehe cearting addreas of thr UPA etorbet reaton which, if present, will albays btart uith the second 32-vord block of the reglon. The first four words of the DPA storage region contain LFA, which vill mrovide the size of the DPA storage reglon. PRiniA then waps the storage region beginning ulth LF::(I) and continuing :hrough the parameter array and returns statuc to :he calling task.

Interac:Ive Access to the Region - An Interactive cask Prup way be run by the user to map the region and provide the user dymanlc access co the parancter values. This task proviles the urer the following caratllties: he may inltiallze all the paranctcrs in the rRy section of the region fron a disk backup Ile; he woy make a copy of the paraseter values in - disik buckup lile: he moy define boaninflul synunyas to be used in referring to sicelfie parametris (desc-lbed under Task PRY, Item 7); he may asign values in Individual parameters; he may dispiay or print out the parameters, i le values and their deflned synonuss; he may scquentially revieu paraweiere at the terminal and sclective:y change values.

Execution of the comands Input by the user is handled in one large loop: The comand is eccelued and parsed, the subroutinc responsible for the particular cosenend is called, env crrurb delceled are reported at the cerminal, and if no errurs are found the comend to execuled. Changes necessary lo the backup flle or to the parameter array In wertory are eade eynchronoully; A.R., 1f a new version of the backup flle lo required, a ceparate lask ia upauned to creale the neu version. But execucton of PRy bales untll ccapletion, hecause following cormonds ulll offect the nev verolon of the backup file.

The Ansociated Diak Flles - Tierc are ewo disk Pijes neresfary to the DPA nubsystem. One, PRH. DAT, contalna the namn of the disk backur file: this allows the ueer to change the name when approprlate ard yee to have the name of the file eadiv ovellable to the DPA onfiuare.

The other diak flle asoociated with DPA Is the mackup flice. is is a directeccess file and conelate of two nafur axclonk. The firnt contalas the parasecters, one per record, consisting of the value and a polnter to the aynonyw defined for the paracelit. If any. The second nection in the ayne w luble: each rocord conening a deflined ivmonver and a puineer back to the paraceser for whlch lt wae delined.

The jeer ay at hila oun cption create fllsk cinteining cexe deceriting che parapetern in the erray. There may he one file for each wertion uf the array, If these fllen exiat, they are uned l.y the commandn whlch diap'ay parameler voluen and arnonva (oep the last parauraph).

\section{DiTAILS OF : UNCTIOHALITY}

This eection diacumang the funcetonalley provided hy the three plecen of UPA coftuare Iram the polit of vleu of the unar. 


\section{Subro'itine PRMCRF}

In the user's task, before the call to DRMCRE, the variables in COYHON RECION carnot be assigned values, because they have virtual addiesaes but no physical addresses until PRiCRE waps the region. An example of the setup of RF.CION follous:

INTFGF.? $\mathrm{HDR}(32), \operatorname{LEN}(4), I(65)$, REST( 1000$)$, ER INTECF.R*4 II(20)

$R F A L=4$ R(IIC)

REAL・B RR ( 23)

LOCICAL・2 FLC, DLD

BYTE PT(6)

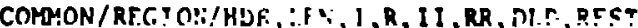

CALL PRMCRE(FLG, PT, HDR, LF.I, I, R, II, RR, ILI, FR)

uhere :

- Fla is true if the reglon 16 to be deleted from wemory when the last task atcached to it is detached, and false If the reglon 18 to be lest In werury. The restar anv then be deleted from mewory hy use ni the PRH Destroy command descrithed later.

- PT 15 the ASCIl representation of the nade of the partition in which the regiun is to be creaced.

- HDR is the 32-word INTFGFe? array whleh contalns offsets to the storage accelons of the region. I: Is pasced to PRyCRE to obcain the virtual addrecs for the ctart of the region.

- LES is the 4-word INTEGER"2 erroy which wlll, following the call to ptyraf, contain the lengehs of tha 4 cectiono of the paragetcr erray.

- $l, R$, II and RR ere the arrovg uhlsh make un the four cections of the paramcter urray.

- PRyCRF. Uill store in DLn the value of FLr. so $1 \mathrm{t}$ can be accessed and aodifled by other uoer laakf a necengary.

- RrSt ig anv ol'ier Information the ueer wants elured in Rrcitok.

- Ek returng alatud co t.e calling routine.

\section{SuSrout Ine PRYMAT}

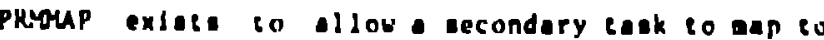
the DPA parameter array in an olready emiselng memory anagenent region ulthout knowing a great any desalle of hou the reglon way be eet up. The call to phreup from the uner's cask da a followa:

COMYON , RE.GION / IIDR, LF.N, ARRAY

CALL. PAPOLAP(HUR, ER)

where:

- HDll In a abuye and 1 s paesed to obtaln the eddrese of phe cesert of the rasion.

- LEN 12 a cbuve.
- ARRAY is dimensioned equal to or larger than the G tze of the whole parancter array as set up by the user's prinary task which created the region. In this manner Array can hc used to access the parazcters withuut knouledge in the cecondary task of the $61 z e s$ of the subsections of the array.

- ER returne otatus to the calling routine.

\section{Togk PRH}

Task PRM Is an Inceract lye task which way access the perory managewent reglon whlle the primary task is running. There are ceveral commands which may be sluen to PRM to provide the user access to the parawe:ers in the reglon. Following is a list of the functions PRM allows the user to perform.

1. Backup Parameter Values - The user can make anapshot of the parameter values in a disk backup file.

2. Set Repion to be Deleted on Last Detach One of the paraweters of the Detach Reglon system service allows bcting whether the regtion should be deleled from memory upon lase detach. A PRy comrand can he used to change thi a seting.

3. Make a New Veroton of the backup Flle This function allows creation of a nes version of the backur disk flle when it is necessary to change the size of the puraweter irray. The user' lask can be ediced and recomplled with no changes wa to the backup file. A coandind can then be used to create new verelon of the backup flle, copying fron the old backup flle the parameter values stlll in use and the aymonyos deftred for thoss parameters, and leaving out parameters not included in the net version of the array or addine parameters ulth values of 0 it the new veruton of the array is larger.

4. Instialize Values in the Reglon - The parapecer values in the reglon can be cet from a beckun file.

5. Scan Porawetera - The user can cxamine and celectively aleer tin values of parameters at tie cerrinal. The sloplay at the cerainal Includes thr paraseter, ton valur. and any aymunvas deflined for ti. After. paragezer 1 s dioplayed, the nker may eype neu value to hr anisaned to the parametel. - carrlage recurn to dieplay the next peraeeter, or a Contrul-z to top scannink.

6. Conerol Veriflcation - The user cat control whethar confimation wunt be plvel before volues in the parameter arr.,y and in the backup lile can be changed.

7. Define a Synunya for a Parame:cr - The ueer cay define aeaningful eymonyas for Individual peragetere. A synonyo mav be definad as an array of "n" elesents, In whteh case it is asuclated ulth the 
parameter and the next $n-1$ paraxeters. example of this is the command it ine

$$
\text { R5 :- NNGLES(5) }
$$

(Parentheses are removed from the subserlpt of a parameter to reduce keystrokes.) Following execution of this comand, the synonvw for R5 is NGLES(1); the symonyo for R6 is ANCLES(2); for R7 1t' ANCLES(3): etc.

The oymony definition is entered in the backup file symonyw table along with the length (for a synonyo arrav) and pointer to the record of the backup ille containing the assoclated parameter. The paraneter way thereafter be referred to in other PRM commands by 1 ts parameter name (e.g., I6) or by 1 ts 8. "nonym.
8. Set the Value of a Paraseter - The value of the parancter is changed to the ney value given (following error checking to be sure the value is appropriate for the parameter (ype) In both the paraceter array in Demory and in tlic backup disk file.

9. Display Parameters - The user can display portions of the paraneter array; an optlonal wodifler may be used to speclfy the output device or ille. The inforation displayed 16 the parameter name, its assoclated synonyw, and its value. If a whole section of the array is displaved, the descripticag from the title flleb are also displayed. 